\title{
Epidemiology, Hot Spots and Socio-Demographic Risk Factors of Alcohol Consumption in Indian Men and Women: Analysis of National Family Health Survey-4, A Nationally Representative Cross Sectional Study
}

\section{Winnie Paulson}

Central University of Tamil Nadu

Balasubramani Karuppusamy

Central University of Tamil Nadu

Savitha Chellappan

National Institute of Traditional Medicine (ICMR)

Sujit Kumar Behera

Central University of Tamil Nadu

Praveen Balabaskaran Nina ( $\sim$ praveen@cutn.ac.in )

Central University of Tamil Nadu https://orcid.org/0000-0003-4096-0738

Research article

Keywords: Alcohol consumption in India, Spatial statistics, NFHS-4, Getis-OrdGi*, Alcohol hot spots in India

Posted Date: June 22nd, 2020

DOI: https://doi.org/10.21203/rs.3.rs-34824/v1

License: (c) (i) This work is licensed under a Creative Commons Attribution 4.0 International License. Read Full License 


\section{Abstract}

\section{Background}

Alcohol consumption is a serious health crisis in India that needs urgent attention. An estimated 160 million Indians consume alcohol. Despite the widespread alcohol use across India, there is no information on the alcohol hot spots. Along with hot spots, understanding the Socio-Demographic Indices (SDI) affecting alcohol consumption in Indian men and women will help guide public health policies on alcohol use.

\section{Methods}

Data from National Family Health Survey-4 carried out from 2015-2016 with a sample size of 103411 men and 699 686 women were used for the analysis. Epidemiology of alcohol use was mapped by Geographic Information System, and hot spots were identified by spatial statistics (Getis-OrdGi*). Bivariate analyses and binary logistic regression were used to analyse SDI.

\section{Results}

India has three major alcohol hot spots: (1) North East (NE) states, (2) Eastern Peninsular states formed by Chhattisgarh, Odisha, Jharkhand and Telangana, and (3) Southern states of Tamil Nadu and Kerala. Among these hot spots, the districts of Tamil Nadu, Telangana and Assam fall under high risk category. Hot spot analysis strongly correlated with region-wise analysis of SDI. South (Men aOR - 1.0, 95\% Cl: 39.1 - 42.1) and NE India (Men aOR - 0.6, 95\% Cl: 38.4 - 42.6; Women aOR - 2.05, 95\% Cl: 6.4 - 7.5) have higher odds of alcohol use. Schedule tribe men (aOR-1.67, 95\% $\mathrm{Cl}$ : 1.53-1.82) and women (aOR-5.99, 95\% Cl: 4.71-7.63) have higher odds of alcohol consumption. Compared to other religions, Muslim men (aOR: 0.11) and women (aOR: 0.06) consume less alcohol

\section{Conclusions}

Hot spots and, high risk districts of alcohol consumption identified in this study can guide public health policies for targeted intervention. Except for religion and social category, other socio-economic factors have a low to moderate effect on alcohol consumption. India does not have concrete anti-alcohol policies at the national level. Alcohol use is at the discretion of individual states and union territories, and appears to be the major determinant of alcohol use in India. Stringent anti-alcohol policies strictly enforced across India is the key to control alcohol use.

\section{Background}

As per WHO, worldwide, an estimated annual 3 million deaths and 5.1\% of the world's Disability- Adjusted Life Years (DALYs) are attributed to alcohol consumption (1). Alcohol use has been linked to 60 acute and chronic disease conditions, especially cancers, liver cirrhosis and cardiovascular diseases such as myocardial infarction, ischemic stroke, elevated blood pressure, coronary heart disease and hemorrhagic stroke (2-7). Alcohol is also indirectly related to increase in road accidents (8).

In India, alcohol consumption is widespread across all the states and union territories (UT), and an estimated 160 million consume alcohol (9). According to National Family Health Survey-4 (NFHS-4), 29.2\% men and 1.2\% women consume alcohol (10). Alcohol use in India is estimated to cause an annual average loss of $1.45 \%$ of the gross domestic product (GDP) of the economy (11). India does not have a solid national policy on alcohol consumption, and its use is regulated at the level of individual states and UT. Despite the widespread alcohol use in India, no information on the statistically significant hot spot clusters of alcohol consumption is available. Even though earlier studies have reported the socio-economic determinants of co-use of alcohol and tobacco, and substance use among North-East (NE) 
men $(12,13)$, the socio-demographic risk factors of alcohol use in Indian men (or women) have not been studied. The data from NFHS-4 was used for Geographic Information System (GIS) and spatial statistics to map the major alcohol hot spots in India. In addition, the high risk states and districts in the hot spots have also been identified for targeted intervention. Furthermore, the Socio Demographic Indices (SDI) have been analyzed separately in men and women to identify the risk factors that influence alcohol consumption.

\section{Methods}

\section{Data source}

The datasets of NFHS-4 carried out by the International Institute of Population Sciences from Jan 20, 2015, to Dec 4, 2016, were used for analysis (10). The data from NFHS-4 is representative of each of India's 640 districts from 29 states and 7 UT for many key health indicators, which also includes alcohol consumption. A multi stage cluster sampling was used for data collection. The 2011 census served as the sampling frame for the selection of villages and households in each district. From the randomly selected households, all the women of the age 15-49 years were asked to participate in the survey. Men of ages 15-54 years were invited to participate from a random subsample of $15 \%$ of these households. The overall sample size of men was 103,411 and women was 699,686 and the age group was 1549 years. The women respondents were considerably higher because the main focus of NFHS-4 was on maternal and child health. The NFHS-4 data were collected using Computer Assisted Personal Interviewing (CAPI) on mini-notebook computers by trained interviewers. Data collection in CAPI will ensure better quality with fewer inconsistencies and missing cases, saves data entry time, and reduces the scope of field editing. Permission to use the NFHS-4 data was obtained from Demographic and Health Survey program (DHS) (12). The administrative boundary and population data of 640 districts of India were obtained from census of India to prepare spatial database in GIS (13). The NFHS-4 survey was funded by United States Agency for International Development. United Nation's Children Fund also assisted the project with supplementary funding support.

\section{Statistical analysis}

The outcome variable was use of any type of alcohol (Yes, No). The socio-economic and demographic characteristics analyzed are type of place of residence (rural, urban), age (15-19, 20-34, 35-49 years), region (North, Central, East, North-East, West and South), educational level (no education, primary, secondary and higher), religion (Hindu, Muslim, Christian and others), social groups (scheduled castes, scheduled tribes, other backward classes, others), wealth quintiles (poorest, poorer, middle, richer, richest), marital status (never married, currently married, others), occupation (not working, professional / managerial, clerical / sales / service, agriculture, skilled / unskilled manual). Descriptive and bivariate statistical analyses were carried out to estimate the prevalence of alcohol consumption under the different socio-economic and demographic variables. The missing values $(<1 \%)$ were not included in the analysis. Binary logistic regression was used to examine the adjusted effect of socio-demographic characteristics on alcohol consumption. The adjusted effect was measured as odds ratio, which is used to determine if an exposure variable is associated with an outcome variable, and also measures the magnitude of association. SPSS software (V-23) was used for analyses, and the results are reported at $95 \%$ confidence interval.

\section{Spatial Analysis}

The district and state level prevalence of men and women alcohol use was linked to administrative boundaries of India using ArcGIS software. This linked spatial database was used to prepare thematic maps to represent the spatial distribution of men and women's alcohol use in India. To understand the hot spots of alcohol consumption in India, we 
used Getis-Ord Gi* spatial autocorrelation tool $(14,15)$. The tool calculates z-scores (standard deviations) and p-values (probability) for each district within the context of neighboring districts (16). In the normal distribution curve, very high (positive) or very low (negative) z-scores with very small p-values populate in the tails. These positive and negative zscores are termed as hot and cold spots respectively. In this analysis, inverse distance squared function was used where closer districts are weighed more heavily than the districts far away. The spatial autocorrelation was executed separately for men and women to identify their hot spots in alcohol consumption. To highlight vulnerable districts / states in terms of alcohol prevalence, a scatter-plot matrix representing men density and alcohol consumption was prepared in GIS. To understand the distribution of different types of alcohol use, a stacked bar diagram was prepared for both men and women.

\section{Results}

\section{Spatial distribution of alcohol consumption}

The state and district- wise comparison of alcohol consumption prevalence in men and women recorded by NFHS-4 is shown in Fig. 1. On an average, only $1.2 \%$ of women in India consume alcohol, whereas the national average for men is $29.2 \%$. Alcohol consumption of both men and women is high in NE and Eastern states of India. In addition, alcohol consumption in men is high in South and North India. In men, high consuming alcohol states are Arunachal Pradesh, Tripura, Telangana, Chattisgarh, Manipur, Sikkim, Mizoram and Tamil Nadu where $>45 \%$ of men consume alcohol. Alcohol prevalence among women is high in all NE states and Telangana.

The district-wise distribution of alcohol consumption in India shows that excluding a few isolated districts of Gujarat, Rajasthan and, Jammu and Kashmir, all the districts of India have alcohol prevalence in excess of 10\% in men (Fig. 1B and Supplementary File 1). Alcohol use is very high (>50\%) in NE India and Eastern peninsular states, especially Telangana and Chattisgarh. In some districts of Arunachal Pradesh (Anjaw and Upper Siang) the prevalence is $100 \%$. Except for NE, Telangana, and border districts in Jharkhand, Chhattisgarh and Odisha, the alcohol consumption among women in all the other districts is quite low $(<2 \%)$. However, many districts in Arunachal Pradesh exceed $30 \%$, and the highest prevalence of alcohol consumption in women (53.2\%) was observed in Alirajpur district of Madhya Pradesh (Fig. 1A and Supplementary File 1).

In India, both men and women, consume different types of alcoholic beverages such as tadi madi, country liquor, hard liquor (spirit), beer, wine or other alcoholic beverages, and the state-wise distribution is given in Fig. 1C. In all the states, more than one type of alcohol are consumed, and overall, there is no single dominant alcoholic beverage in India.

However, hard liquor with high alcohol content is highly consumed in Mizoram, Tamil Nadu, Meghalaya, Nagaland and Kerala. The proportion of Tadi madi / country liquor is higher in the tribal dominated states of Tripura, Chhattisgarh, Jharkhand, Assam, Odisha and Madhya Pradesh. Compared to men, women in these states mostly prefer tadi madi / country liquor. Beer and wine constitute the largest proportion of alcohol consumed in the small states (Sikkim and Goa) and UT (Andaman and Nicobar, Daman and Diu, Dadra and Nagar, and Puducherry).

\section{Hot Spots Of Alcohol Consumption}

We employed Getis-Ord Gi* statistic to identify statistically significant spatial clusters of alcohol prevalence among men and women. To form a statistically significant hot spot, the district with high prevalence should be surrounded by districts with high prevalence. Based on z-scores and p-values, hot spots of alcohol consumption for men and women are shown with 99\%, 95\% and 90\% confidence intervals (Fig. 2A, 2B and Supplementary Table 1). There are three significant alcohol hot spots in India. NE states form the first and prominent hot spot of alcohol consumption in India 
for both men and women. Due to lack of data from the neighboring districts, some of the border districts in the NE hot spot are excluded from the results. However, individual consumption rates of those districts are high, and hence we consider the entire NE region as a hot spot. The second hot spot is formed primarily by the districts of Chhattisgarh, Odisha, Jharkhand and Telangana states of the Eastern peninsular region. This hot spot is more pronounced in men, and also extends to the western districts of Madhya Pradesh and North-Eastern districts of Andhra Pradesh. In women, the second hot spot is split into two - the districts in the borders of Jharkhand, Chattisgarh and Odisha form one cluster, and the second cluster is formed by Telangana (excluding the Northern districts), and the Southern districts of Jharkhand. Most of the districts in NE and Eastern peninsular hot spots (Jharkhand, Chhattisgarh and Odisha) have high proportion of Scheduled Tribes (ST) (>75\%). The bifurcation of the women's alcohol hot spot in the Eastern peninsular region coincides with the distribution of the ST women population (Fig. 2A).

The third hot spot is formed by the districts of Tamil Nadu and South Kerala, and is seen only in men. Tamil Nadu is a cold spot for women. The cold spots cover majority of the districts in Western and Northern India, excluding the states of Punjab, Himachal Pradesh and Uttarkhand, where alcohol consumption is moderately high.

Even though the consumption of alcohol is very high in NE, population density in this region, especially in Arunachal Pradesh and Tripura is very low compare to the rest of India. In order to identify vulnerable districts / states in terms of population density and high alcohol prevalence, scatter plot analysis was carried with the district-level consumption in men (\%) and men density (per sq.km) (Fig. 2C). The analysis shows that among the three hot spots, the districts of Tamil Nadu, Telangana and Assam are highly vulnerable. In the high risk metro districts of Chennai (Tamil Nadu), Hyderabad (Telangana) and Kolkata (West Bengal), the men density exceeds 10,000 per sq.km and alcohol consumption rate is more than $40 \%$.

\section{Sdi Affecting Alcohol Consumption In Indian Men And Women}

The prevalence of alcohol consumption among men and women aged 15-49 years by different SDI and adjusted odds ratios (aOR) are given in Table 1. The socio-demographic profile of the respondents aged 15-49 years is given in the Supplementary Table 2. 
Table 1

Prevalence of alcohol use among survey participants age 15-49 years by socio- economic characteristics, India, NFHS-

4

\begin{tabular}{|c|c|c|c|c|c|c|c|c|}
\hline \multirow{2}{*}{$\begin{array}{l}\text { Socio- } \\
\text { Economic } \\
\text { Characteristics }\end{array}$} & \multicolumn{4}{|l|}{ Alcohol Men } & \multicolumn{4}{|c|}{ Alcohol Women } \\
\hline & $\begin{array}{l}\text { Prevalence } \\
\text { n (\%) }\end{array}$ & $\begin{array}{l}95 \% \\
\mathrm{Cl}\end{array}$ & $\begin{array}{l}\text { Adjusted } \\
\text { Odds } \\
\text { Ratio } \\
\text { (aOR) }\end{array}$ & $95 \% \mathrm{Cl}$ & $\begin{array}{l}\text { Prevalence } \\
\text { n (\%) }\end{array}$ & $\begin{array}{l}95 \% \\
\mathrm{Cl}\end{array}$ & $\begin{array}{l}\text { Adjusted } \\
\text { Odds } \\
\text { Ratio } \\
\text { (aOR) }\end{array}$ & $95 \% \mathrm{Cl}$ \\
\hline \multicolumn{9}{|c|}{ Place of Residence } \\
\hline Rural & 18827(29.5) & $\begin{array}{l}28.9- \\
30.1\end{array}$ & $0.85^{\star \star}$ & $\begin{array}{l}0.79- \\
0.92\end{array}$ & $6920(1.5)$ & $\begin{array}{l}1.4- \\
1.6\end{array}$ & 1.01 & $\begin{array}{l}0.75^{-} \\
1.36\end{array}$ \\
\hline Urban & 11339(28.7) & $\begin{array}{l}27.4- \\
29.9\end{array}$ & $\begin{array}{l}\text { Reference } \\
(1.0)\end{array}$ & $\begin{array}{l}\text { Reference } \\
(1.0)\end{array}$ & $1717(0.7)$ & $\begin{array}{l}0.6- \\
0.8\end{array}$ & $\begin{array}{l}\text { Reference } \\
(1.0)\end{array}$ & $\begin{array}{l}\text { Reference } \\
(1.0)\end{array}$ \\
\hline \multicolumn{9}{|l|}{ Age } \\
\hline $15-24$ & $5686(16.1)$ & $\begin{array}{l}15.4- \\
16.8\end{array}$ & $0.65^{\star \star}$ & $\begin{array}{l}0.60- \\
0.72\end{array}$ & $1516(0.6)$ & $\begin{array}{l}0.6- \\
0.7\end{array}$ & $0.61 * \star$ & $\begin{array}{l}0.48- \\
0.74\end{array}$ \\
\hline $25-39$ & 15865(35.6) & $\begin{array}{l}34.7- \\
36.5\end{array}$ & 1.11 *夫 & $\begin{array}{l}1.04- \\
1.18\end{array}$ & 3992(1.3) & $\begin{array}{l}1.2- \\
1.4\end{array}$ & $0.81 *$ & $\begin{array}{l}0.68- \\
0.96\end{array}$ \\
\hline $40-49$ & $8614(36.7)$ & $\begin{array}{l}35.7- \\
37.7\end{array}$ & $\begin{array}{l}\text { Reference } \\
(1.0)\end{array}$ & $\begin{array}{l}\text { Reference } \\
(1.0)\end{array}$ & $3128(2.1)$ & $\begin{array}{l}1.9- \\
2.2\end{array}$ & $\begin{array}{l}\text { Reference } \\
(1.0)\end{array}$ & $\begin{array}{l}\text { Reference } \\
(1.0)\end{array}$ \\
\hline \multicolumn{9}{|l|}{ Region } \\
\hline North & $3433(23.1)$ & $\begin{array}{l}22.2- \\
24.1\end{array}$ & $0.31^{* \star}$ & $\begin{array}{l}0.28- \\
0.34\end{array}$ & $171(0.2)$ & $\begin{array}{l}0.1- \\
0.2\end{array}$ & $0.08^{\star \star}$ & $\begin{array}{l}0.03- \\
0.22\end{array}$ \\
\hline Central & $6149(27.4)$ & $\begin{array}{l}26.5- \\
28.2\end{array}$ & $0.3^{* \star}$ & $\begin{array}{l}0.27- \\
0.33\end{array}$ & $1566(1.0)$ & $\begin{array}{l}0.9- \\
1.1\end{array}$ & $0.28 * \star$ & $\begin{array}{l}0.21- \\
0.37\end{array}$ \\
\hline East & 6117(31.7) & $\begin{array}{l}30.0- \\
33.5\end{array}$ & $0.41^{\star \star}$ & $\begin{array}{l}0.36- \\
0.46\end{array}$ & 1911(1.2) & $\begin{array}{l}1.1- \\
1.3\end{array}$ & $0.29 * \star$ & $\begin{array}{l}0.21- \\
0.39\end{array}$ \\
\hline North- East & $1376(40.5)$ & $\begin{array}{l}38.4- \\
42.6\end{array}$ & $0.6^{\star *}$ & $\begin{array}{l}0.53- \\
0.68\end{array}$ & $1561(6.9)$ & $\begin{array}{l}6.4^{-} \\
7.5\end{array}$ & $2.05^{\star \star}$ & $\begin{array}{l}1.44- \\
2.92\end{array}$ \\
\hline West & $3246(17.0)$ & $\begin{array}{l}15.5^{-} \\
18.5\end{array}$ & 0.16 ** & $\begin{array}{l}0.14- \\
0.18\end{array}$ & $277(0.3)$ & $\begin{array}{l}0.2- \\
0.4\end{array}$ & 0.08 ** & $\begin{array}{l}0.05- \\
0.14\end{array}$ \\
\hline South & $9842(40.6)$ & $\begin{array}{l}39.1- \\
42.1\end{array}$ & $\begin{array}{l}\text { Reference } \\
(1.0)\end{array}$ & $\begin{array}{l}\text { Reference } \\
(1.0)\end{array}$ & $2887(1.8)$ & $\begin{array}{l}1.6- \\
2.0\end{array}$ & $\begin{array}{l}\text { Reference } \\
(1.0)\end{array}$ & $\begin{array}{l}\text { Reference } \\
(1.0)\end{array}$ \\
\hline \multicolumn{9}{|c|}{ Educational Level } \\
\hline No Education & 4876(39.9) & $\begin{array}{l}38.5- \\
41.3\end{array}$ & $1.13^{*}$ & $\begin{array}{l}1.02- \\
1.26\end{array}$ & $5074(2.6)$ & $\begin{array}{l}2.5- \\
2.8\end{array}$ & $1.83^{\star \star}$ & $\begin{array}{l}1.19- \\
2.82\end{array}$ \\
\hline Primary & $4537(36.6)$ & $\begin{array}{l}35.2- \\
38.0\end{array}$ & 1.05 & $\begin{array}{l}0.94- \\
1.17\end{array}$ & $970(1.1)$ & $\begin{array}{l}1.0- \\
1.2\end{array}$ & 0.97 & $\begin{array}{l}0.61- \\
1.54\end{array}$ \\
\hline Secondary & 16337(27.1) & $\begin{array}{l}26.4- \\
27.8\end{array}$ & 0.97 & $\begin{array}{l}0.89- \\
1.05\end{array}$ & 1977(0.6) & $\begin{array}{l}0.5- \\
0.7\end{array}$ & 0.79 & $\begin{array}{l}0.53- \\
1.18\end{array}$ \\
\hline
\end{tabular}

Cl- Confidence Interval

** $P<0.01$

$* P<0.05$ 


\begin{tabular}{|c|c|c|c|c|c|c|c|c|}
\hline \multirow{2}{*}{$\begin{array}{l}\text { Socio- } \\
\text { Economic } \\
\text { Characteristics }\end{array}$} & \multicolumn{4}{|l|}{ Alcohol Men } & \multicolumn{4}{|c|}{ Alcohol Women } \\
\hline & $\begin{array}{l}\text { Prevalence } \\
\text { n (\%) }\end{array}$ & $\begin{array}{l}95 \% \\
\mathrm{Cl}\end{array}$ & $\begin{array}{l}\text { Adjusted } \\
\text { Odds } \\
\text { Ratio } \\
\text { (aOR) }\end{array}$ & $95 \% \mathrm{Cl}$ & $\begin{array}{l}\text { Prevalence } \\
\text { n (\%) }\end{array}$ & $\begin{array}{l}95 \% \\
\mathrm{Cl}\end{array}$ & $\begin{array}{l}\text { Adjusted } \\
\text { Odds } \\
\text { Ratio } \\
\text { (aOR) }\end{array}$ & $95 \% \mathrm{Cl}$ \\
\hline
\end{tabular}

\begin{tabular}{|c|c|c|c|c|c|c|c|c|}
\hline Higher & $4415(24.0)$ & $\begin{array}{l}22.7- \\
25.2\end{array}$ & $\begin{array}{l}\text { Reference } \\
(1.0)\end{array}$ & $\begin{array}{l}\text { Reference } \\
(1.0)\end{array}$ & $615(0.7)$ & $\begin{array}{l}0.6- \\
0.8\end{array}$ & $\begin{array}{l}\text { Reference } \\
(1.0)\end{array}$ & $\begin{array}{l}\text { Reference } \\
(1.0)\end{array}$ \\
\hline \multicolumn{9}{|l|}{ Religion } \\
\hline Hindu & 26585(31.6) & $\begin{array}{l}30.9- \\
32.2\end{array}$ & 0.48 ** & $\begin{array}{l}0.41- \\
0.58\end{array}$ & $7323(1.3)$ & $\begin{array}{l}1.2- \\
1.4\end{array}$ & $0.36 * \star$ & $\begin{array}{l}0.27- \\
0.48\end{array}$ \\
\hline Muslim & $1561(11.3)$ & $\begin{array}{l}10.2- \\
12.5\end{array}$ & $0.11^{\star \star}$ & $\begin{array}{l}0.09- \\
0.14\end{array}$ & $137(0.1)$ & $\begin{array}{l}0.1- \\
0.2\end{array}$ & $0.06 * \star$ & $\begin{array}{l}0.02- \\
0.15\end{array}$ \\
\hline Christian & $973(42.8)$ & $\begin{array}{l}39.6- \\
46.0\end{array}$ & $0.53^{\star \star}$ & $\begin{array}{l}0.42- \\
0.66\end{array}$ & $668(4.0)$ & $\begin{array}{l}3.5^{-} \\
4.6\end{array}$ & $0.25^{\star \star}$ & $\begin{array}{l}0.16- \\
0.41\end{array}$ \\
\hline Others & 1046(33.4) & $\begin{array}{l}30.8- \\
36.2\end{array}$ & $\begin{array}{l}\text { Reference } \\
(1.0)\end{array}$ & $\begin{array}{l}\text { Reference } \\
(1.0)\end{array}$ & $508(2.2)$ & $\begin{array}{l}2.0- \\
2.5\end{array}$ & $\begin{array}{l}\text { Reference } \\
(1.0)\end{array}$ & $\begin{array}{l}\text { Reference } \\
(1.0)\end{array}$ \\
\hline \multicolumn{9}{|l|}{ Social Category } \\
\hline Others & $5188(21.6)$ & $\begin{array}{l}20.4- \\
22.8\end{array}$ & 0.88 * & $\begin{array}{l}0.81- \\
0.96\end{array}$ & $754(0.5)$ & $\begin{array}{l}0.4- \\
0.6\end{array}$ & $1.5^{\star}$ & $\begin{array}{l}1.07- \\
2.11\end{array}$ \\
\hline $\begin{array}{l}\text { Schedule } \\
\text { Caste }\end{array}$ & $7442(36.3)$ & $\begin{array}{l}35.1- \\
37.6\end{array}$ & $1.22^{\star \star}$ & $\begin{array}{l}1.13- \\
1.31\end{array}$ & $1251(0.9)$ & $\begin{array}{l}0.8- \\
1.0\end{array}$ & 1.02 & $\begin{array}{l}0.77- \\
1.36\end{array}$ \\
\hline Schedule Tribe & $3775(41.3)$ & $\begin{array}{l}39.7- \\
43.0\end{array}$ & $1.67 \star \star$ & $\begin{array}{l}1.53- \\
1.82\end{array}$ & $4145(6.5)$ & $\begin{array}{l}6.1- \\
6.9\end{array}$ & $5.99 * \star$ & $\begin{array}{l}4.71- \\
7.63\end{array}$ \\
\hline $\begin{array}{l}\text { Other } \\
\text { Backward } \\
\text { Classes }\end{array}$ & $12872(28.5)$ & $\begin{array}{l}27.7- \\
29.4\end{array}$ & $\begin{array}{l}\text { Reference } \\
(1.0)\end{array}$ & $\begin{array}{l}\text { Reference } \\
(1.0)\end{array}$ & $2229(0.7)$ & $\begin{array}{l}0.7- \\
0.8\end{array}$ & $\begin{array}{l}\text { Reference } \\
(1.0)\end{array}$ & $\begin{array}{l}\text { Reference } \\
(1.0)\end{array}$ \\
\hline \multicolumn{9}{|l|}{ Wealth Index } \\
\hline Poorest & $5387(35.4)$ & $\begin{array}{l}34.2- \\
36.6\end{array}$ & 0.95 & $\begin{array}{l}0.85- \\
1.06\end{array}$ & $3596(2.9)$ & $\begin{array}{l}2.8^{-} \\
3.1\end{array}$ & $1.75^{\star \star}$ & $\begin{array}{l}1.24- \\
2.48\end{array}$ \\
\hline Poorer & $5796(29.9)$ & $\begin{array}{l}28.8- \\
31.0\end{array}$ & $0.83^{\star \star}$ & $\begin{array}{l}0.75- \\
0.92\end{array}$ & 1931(1.4) & $\begin{array}{l}1.3- \\
1.5\end{array}$ & 0.93 & $\begin{array}{l}0.65- \\
1.34\end{array}$ \\
\hline
\end{tabular}

Cl- Confidence Interval

** $P<0.01$;

* $P<0.05$ 


\begin{tabular}{|c|c|c|c|c|c|c|c|c|}
\hline \multirow{2}{*}{$\begin{array}{l}\text { Socio- } \\
\text { Economic } \\
\text { Characteristics }\end{array}$} & \multicolumn{4}{|l|}{ Alcohol Men } & \multicolumn{4}{|c|}{ Alcohol Women } \\
\hline & $\begin{array}{l}\text { Prevalence } \\
\text { n (\%) }\end{array}$ & $\begin{array}{l}95 \% \\
\mathrm{Cl}\end{array}$ & $\begin{array}{l}\text { Adjusted } \\
\text { Odds } \\
\text { Ratio } \\
\text { (aOR) }\end{array}$ & $95 \% \mathrm{Cl}$ & $\begin{array}{l}\text { Prevalence } \\
\text { n (\%) }\end{array}$ & $\begin{array}{l}95 \% \\
\mathrm{Cl}\end{array}$ & $\begin{array}{l}\text { Adjusted } \\
\text { Odds } \\
\text { Ratio } \\
\text { (aOR) }\end{array}$ & $95 \% \mathrm{Cl}$ \\
\hline Middle & $6623(30.0)$ & $\begin{array}{l}29.0 \\
-31.1\end{array}$ & $0.88^{*}$ & $\begin{array}{l}0.80- \\
0.97\end{array}$ & $1367(1.0)$ & $\begin{array}{l}0.9- \\
1.1\end{array}$ & 0.8 & $\begin{array}{l}0.55^{-} \\
1.17\end{array}$ \\
\hline Richer & $6376(27.8)$ & $\begin{array}{l}26.6- \\
29.0\end{array}$ & $0.87 * *$ & $\begin{array}{l}0.79- \\
0.96\end{array}$ & $829(0.6)$ & $\begin{array}{l}0.5- \\
0.6\end{array}$ & 0.84 & $\begin{array}{l}0.57- \\
1.24\end{array}$ \\
\hline Richest & 5982(25.1) & $\begin{array}{l}23.8- \\
26.5\end{array}$ & $\begin{array}{l}\text { Reference } \\
(1.0)\end{array}$ & $\begin{array}{l}\text { Reference } \\
(1.0)\end{array}$ & $911(0.6)$ & $\begin{array}{l}0.5- \\
0.7\end{array}$ & $\begin{array}{l}\text { Reference } \\
(1.0)\end{array}$ & $\begin{array}{l}\text { Reference } \\
(1.0)\end{array}$ \\
\hline \multicolumn{9}{|l|}{ Marital Status } \\
\hline Never Married & 7406(18.7) & $\begin{array}{l}17.9- \\
19.5\end{array}$ & 0.82 & $\begin{array}{l}0.66- \\
1.03\end{array}$ & $1035(0.7)$ & $\begin{array}{l}0.6- \\
0.7\end{array}$ & 1.05 & $\begin{array}{l}0.73- \\
1.52\end{array}$ \\
\hline Married & 22242(35.6) & $\begin{array}{l}34.8- \\
36.3\end{array}$ & 0.89 & $\begin{array}{l}0.72- \\
1.14\end{array}$ & $6765(1.3)$ & $\begin{array}{l}1.3- \\
1.4\end{array}$ & 0.8 & $\begin{array}{l}0.62- \\
1.04\end{array}$ \\
\hline Others & $517(40.4)$ & $\begin{array}{l}35.9- \\
45.1\end{array}$ & $\begin{array}{l}\text { Reference } \\
(1.0)\end{array}$ & $\begin{array}{l}\text { Reference } \\
(1.0)\end{array}$ & $837(2.9)$ & $\begin{array}{l}2.5- \\
3.2\end{array}$ & $\begin{array}{l}\text { Reference } \\
(1.0)\end{array}$ & $\begin{array}{l}\text { Reference } \\
(1.0)\end{array}$ \\
\hline \multicolumn{9}{|l|}{ Occupation } \\
\hline Not Working & 3322(13.9) & $\begin{array}{l}13.2- \\
14.7\end{array}$ & $0.49 * *$ & $\begin{array}{l}0.44- \\
0.53\end{array}$ & $607(0.7)$ & $\begin{array}{l}0.6- \\
0.8\end{array}$ & $0.55^{\star \star}$ & $\begin{array}{l}0.44- \\
0.69\end{array}$ \\
\hline $\begin{array}{l}\text { Professional / } \\
\text { Managerial }\end{array}$ & 1801(27.1) & $\begin{array}{l}25.2- \\
29.2\end{array}$ & $0.73^{\star \star}$ & $\begin{array}{l}0.63- \\
0.83\end{array}$ & $43(1.2)$ & $\begin{array}{l}0.6- \\
2.4\end{array}$ & 0.72 & $\begin{array}{l}0.38- \\
1.36\end{array}$ \\
\hline $\begin{array}{l}\text { Clerical / } \\
\text { Sales / } \\
\text { Services }\end{array}$ & $6236(32.8)$ & $\begin{array}{l}31.3- \\
34.3\end{array}$ & 0.92 & $\begin{array}{l}0.84- \\
1.01\end{array}$ & $123(1.9)$ & $\begin{array}{l}1.2- \\
3.1\end{array}$ & 0.86 & $\begin{array}{l}0.58- \\
1.27\end{array}$ \\
\hline Agricultural & $8607(32.2)$ & $\begin{array}{l}31.2- \\
33.1\end{array}$ & $0.69 * *$ & $\begin{array}{l}0.64- \\
0.73\end{array}$ & 535(3.0) & $\begin{array}{l}2.6- \\
3.5\end{array}$ & 1 & $\begin{array}{l}0.79- \\
1.27\end{array}$ \\
\hline $\begin{array}{l}\text { Skilled / } \\
\text { Unskilled } \\
\text { Manual }\end{array}$ & 10148(37.7) & $\begin{array}{l}36.5^{-} \\
38.8\end{array}$ & $\begin{array}{l}\text { Reference } \\
(1.0)\end{array}$ & $\begin{array}{l}\text { Reference } \\
(1.0)\end{array}$ & $185(2.4)$ & $\begin{array}{l}2.0- \\
3.0\end{array}$ & $\begin{array}{l}\text { Reference } \\
(1.0)\end{array}$ & $\begin{array}{l}\text { Reference } \\
(1.0)\end{array}$ \\
\hline \multicolumn{9}{|c|}{ Cl- Confidence Interval } \\
\hline \multicolumn{9}{|l|}{$* * P<0.01$} \\
\hline$* P<0.05$ & & & & & & & & \\
\hline
\end{tabular}

South Indian men (aOR: 1), and NE men (aOR: 0.6) and women (aOR: 2.5) consume more alcohol. The place of residence (urban or rural) does not influence the consumption pattern in both men and women. Alcohol consumption among women increases with age, and is higher in women greater than 40 years (aOR: 0.61, 0.81 and 1.0 respectively for 15-24, 25-39 and > 40 years). Alcohol use is higher in men > 25 years. Married women consume less alcohol, while married and divorced / separated men consume more alcohol than never married.

Women from the poorest wealth index (aOR: 1.75), and uneducated background (aOR: 1.83) have high prevalence of alcohol consumption compared to the richest and highly educated. When occupation was analyzed in women, manual 
laborers (aOR: 1.0) and agricultural workers (aOR: 1.0) consumed more alcohol than other class of workers, while in men, no such association were observed.

Among the SDI, religion and social category had the greatest influence on alcohol use. Compared to other religions, Muslim men (aOR: 0.11) and women (aOR: 0.06) consume less alcohol. Among the different social categories in men, scheduled tribes (aOR: 1.67) and scheduled castes (aOR: 1.22) have higher alcohol prevalence. Compared to the Other Backward Castes (OBC), ST women have six times higher odds of consuming alcohol.

\section{Discussion}

Alcohol consumption is a leading cause of global disease burden and health loss, and in 2016, was ranked seventh in risk factors linked to deaths and DALYs (19). The global alcohol use and burden study shows that health loss is associated with all levels of consumption (19), challenging few studies that suggest low level of alcohol consumption may be protective against certain disease outcomes (20-22). Alcohol consumption is widespread across India, and an estimated 160 million consume alcohol (9). In addition to the health burden, alcohol consumption in India has serious social consequences such as domestic violence, lower quality of life, strained relationship with family members, psychological and emotional effects on children that adversely impacts

education $(23,24)$. Compared to NFHS-3 (2005-06), alcohol consumption in men has decreased by just $2.7 \%$ in NFHS-4 (2015-16), a negligible decline (10). Our findings over the two surveys indicate that alcohol consumption is similar in many of the states, and has increased in Tamil Nadu, Himachal Pradesh, Tripura and Mizoram. The lack of a national policy on alcohol control is the major reason for the high alcohol consumption across India. The state governments are empowered to manufacture, distribute and regulate the sale and use of alcohol (25).Except for Gujarat, Bihar (ban from 2016), Lakshadweep, Mizoram (ban from 2018) and Manipur (partial ban), alcohol consumption is legal in all the other states and UT. For many state governments, taxation from alcohol is an important source of revenue (25). For example, Tamil Nadu distributes and sells alcohol through its 5152 own outlets and adds over $30 \%$ revenue (> Rs.30 000 crore / year) to its exchequer (26).

NFHS-4 findings indicate that alcohol consumption is seen predominantly in men (29.2\%). Peer pressure, habituation, stress and tiredness from work are attributed as reasons for alcohol use in Indian men (23). Social and cultural characteristics of the Indian society greatly limit consumption of alcohol by Indian women (27); only 1.2\% women consume alcohol. Prevalence of alcohol was higher in men between 25 and 39 years (35.6\%), and as seen in many countries (28), did not decrease with age (40-49 years $-36.7 \%)$; these findings strongly suggest that men are addicted.

The district-wise distribution and subsequent hot spot analysis show that the NE region forms the first hot spot. Almost all the districts of Chattisgarh, Odisha, Telangana and Northeastern Andhra Pradesh constitute the second hot spot, and the third hot spot is made up by all the districts of Tamil Nadu and Southern districts of Kerala. The NE region shares porous international borders with Myanmar and Bangladesh, and the easy availability of cheap tobacco and alcohol in NE smuggled through these countries could be a major reason for the high prevalence (29). Even though, the consumption of alcohol is very high in the NE states, the alcohol consumers per sq.km are less (except in Assam). Among the hot spots, based on population density and alcohol consumption, the high risk districts are in Tamil Nadu, Telangana and Assam. In addition, the high proportion of hard liquor (contains 40\% alcohol by volume) consumers in Tamil Nadu and Telangana strongly indicate addiction. Not surprisingly, road accidents associated with drunken driving in Tamil Nadu is among the highest in India (30).

Our analysis shows that most of the SDI have low to moderate association with alcohol use. Religion and social category had a major influence on alcohol consumption. Alcohol use is lower in Muslims (Men - 11.3\%; Women - 0.1\%), 
as Islam prohibits alcohol consumption (31). Our findings indicate that most of the districts with high consumption of alcohol, especially women alcohol hot spots, coincide with districts with high proportion of ST population. The multi logistic regression analysis also indicates a strong association between ST population and alcohol consumption in men (aOR: 1.67) and women (aOR: 5.99); 75\% of alcohol consuming women are ST. In women, high alcohol consumption is also seen among the poorest, individuals with no education, and in manual / agricultural workers. ST have very low literacy rates, are most economically backward, and majority of them are manual / agricultural workers (32).

Overall, except for region (South - men; NE - men and women), religious faith (Islam), and social category (SC and ST men; ST - women), the other socio-demographic determinants do not appear to strongly affect alcohol consumption.

As the study is based on a cross- sectional survey, a major limitation is it is not possible to measure the direction of association between the socio-demographic characteristics and the outcome variables. Furthermore, alcohol use was self-reported by the survey participants, hence there is a chance of under or over reporting. Even though the majority of alcohol users in India were men, the sample size of women in the survey was nearly 7 times higher than men as the survey's primary focus was on maternal and child health.

\section{Conclusions}

Hot spots and vulnerable districts in the hot spots have to be given priority for targeted intervention. Health awareness programs, especially for scheduled tribe women have to be implemented. Alcohol policy of the individual states and UT appears to be the key determinant of alcohol use in India. Unfettered access to alcohol in most states have led to high prevalence, and addiction. In a low middle income country like India, the amount of money spent on tobacco and alcohol by millions of Indians on a daily basis would have a direct bearing on the quality of life. Strong anti-alcohol policies have to be implemented strictly across India to protect the financial, mental and physical health of millions of Indian families.

\section{Abbreviations}

SDI - Socio-Demographic Indices; NFHS-4 - National Family Health Survey-4; NE

North-East; ST - Scheduled Tribes; DHS - Demographic and Health Survey program

\section{Declarations}

\section{Ethics approval and consent to participate}

The study was approved by the Institutional Review Boards of the institutions involved. Verbal consent was obtained from the volunteers. The datasets are available for public at www.dhsprogram.com for research analysis.

\section{Consent for publication}

Not applicable

\section{Availability of data and materials}

The datasets analyzed in the current study are available for public use at www.dhsprogram.com

\section{Competing interests}


The authors declare that they have no competing interests

\section{Funding}

Not applicable

\section{Authors' contributions}

WP, BK and PBN - Contributed to the study design, data collection, data analysis, figures, data interpretation, literature search and writing. SC and SKB - Contributed to the literature search, data analysis and interpretation. All authors have read and approved the manuscript.

\section{Acknowledgements}

We thank DHS program for giving permission to use the NFHS-4 datasets

\section{References}

1. Hammer JHPM, Spiker DA,. Global status report on alcohol and health: World Health Organization; 2018. Available from: http://www.who.int/substance_abuse/publications/global_alcohol_report/msbgsruprofiles.pdf\%0 (Accessed on February 1, 2020).

2. Ezzati M, Hoorn SV, Lopez AD, Danaei G, Rodgers A, Mathers CD, et al. Comparative Quantification of Mortality and Burden of Disease Attributable to Selected Risk Factors. In: Lopez AD, Mathers CD, Ezzati M, Jamison DT, Murray CJL, editors Global Burden of Disease and Risk Factors. Washington (DC)2006.

3. Rehm J, Room R, Graham K, Monteiro M, Gmel G, Sempos CT. The relationship of average volume of alcohol consumption and patterns of drinking to burden of disease: an overview. Addiction. 2003;98(9):1209-28.

4. Rehm J, Room R, Monteiro M, Gmel G, Graham K, Rehn N, et al. Alcohol as a risk factor for global burden of disease. Eur Addict Res. 2003;9(4):157-64.

5. Rao VG, Bhat J, Yadav R, Muniyandi M, Bhondeley MK, Wares DF. Smoking and alcohol consumption: Risk factors for pulmonary tuberculosis among the tribal community in central India. Indian J Tuberc. 2017;64(1):40-3.

6. Mostofsky E, Chahal HS, Mukamal KJ, Rimm EB, Mittleman MA. Alcohol and Immediate Risk of Cardiovascular Events: A Systematic Review and Dose-Response Meta-Analysis. Circulation. 2016;133(10):979-87.

7. Roerecke M, Vafaei A, Hasan OSM, Chrystoja BR, Cruz M, Lee R, et al. Alcohol Consumption and Risk of Liver Cirrhosis: A Systematic Review and Meta-Analysis. Am J Gastroenterol. 2019;114(10):1574-86.

8. Das A, Gjerde H, Gopalan SS, Normann PT. Alcohol, drugs, and road traffic crashes in India: a systematic review. Traffic Inj Prev. 2012;13(6):544-53.

\section{Figures}




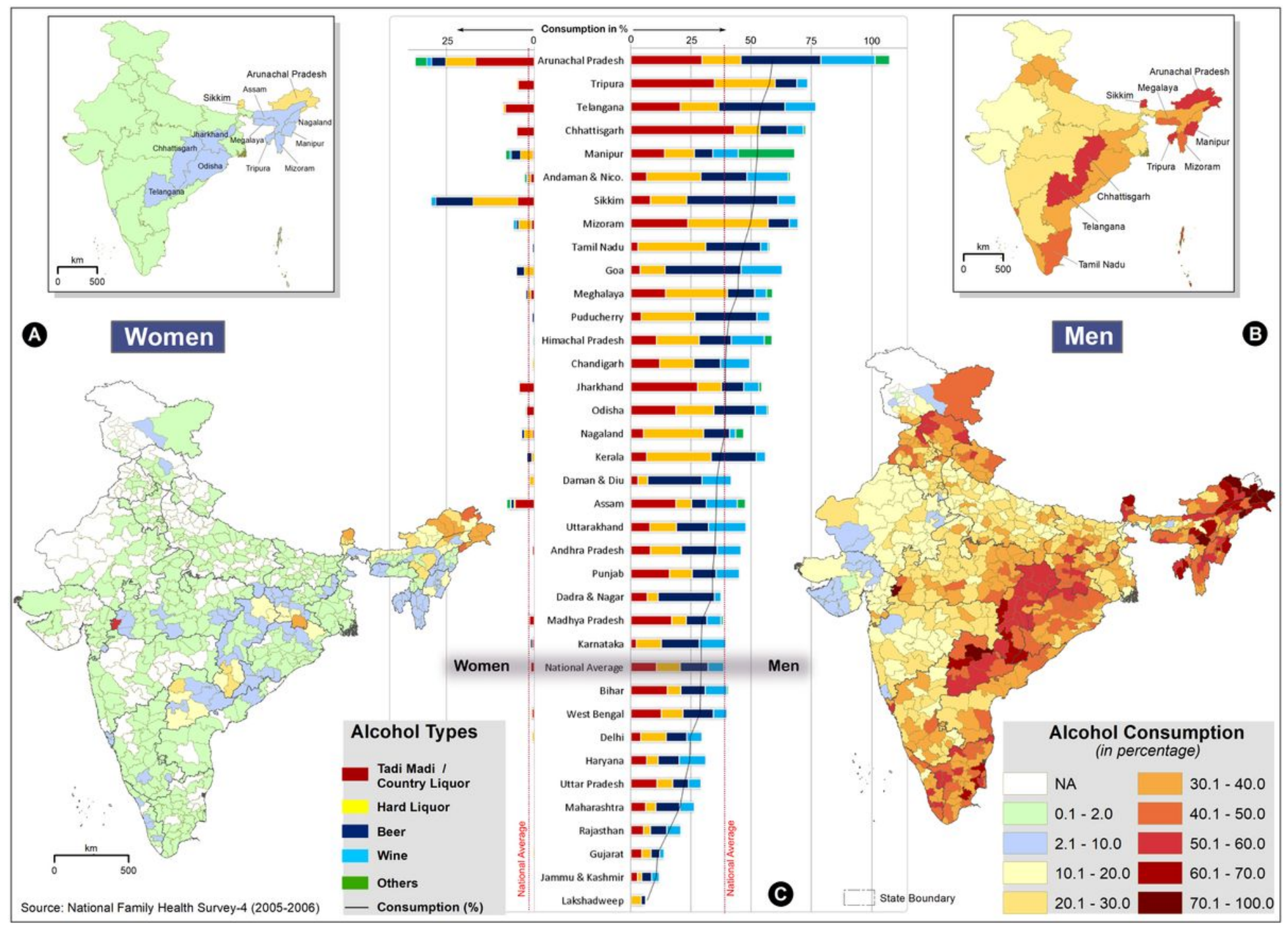

Figure 1

State and District-wise comparison of alcohol consumption in men and women, NFHS-4. The inset maps (top) show the state-wise average, and the bottom maps show the district-wise alcohol distribution for women $(A)$ and men $(B)$. The darker red shades denote higher consumption. The state boundaries are overlaid to show inter-intra state distributions. The state-wise comparison of different types of alcohol consumption is shown for men (right bars) and women (left bars), along with the percentage of alcohol consumption (dark line over bars) (C). The red dotted lines show the national average of all forms of alcohol consumption. The bars exceeding the red dotted lines indicate the states that fall above or below the national average of alcohol consumption. The bars exceeding the dark lines indicate men consume more than one type of alcohol. 


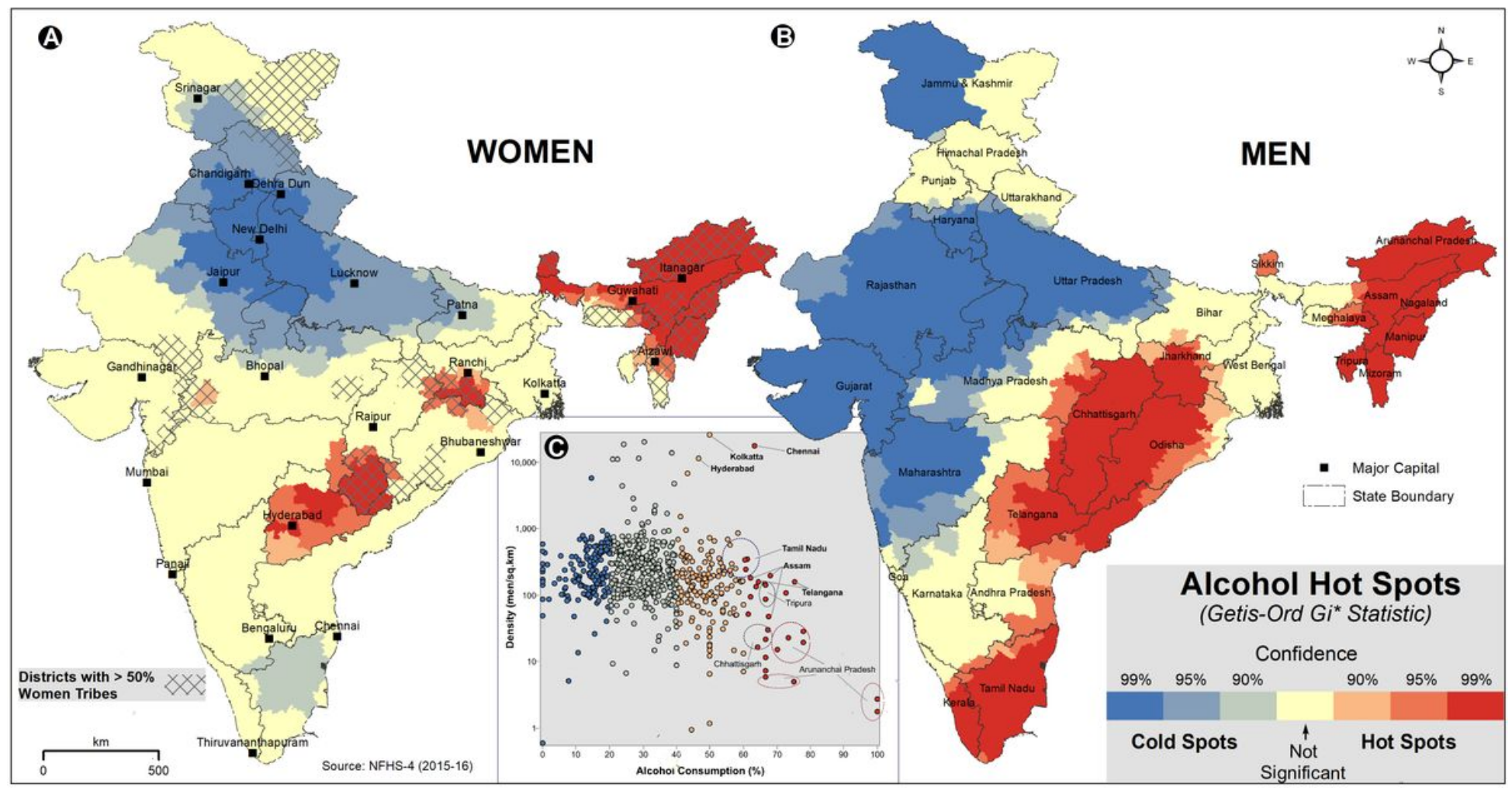

Figure 2

Hot spot analysis of alcohol consumption in India, NFHS-4. The hot (red) and cold (blue) spots of alcohol consumption with three confidence levels (99\%, 95\% and $90 \%)$ are shown for women (A) and men (B). The light yellow colour shows the spatially not-significant districts of alcohol consumption. The overlaid hatches (A) indicates that more than 50 percent of women are ST in that district. Scatter plot (C) shows the relationship between alcohol consumption and density. The dots represent district values of alcohol consumption of men (\%) and men density per sq.km.

\section{Supplementary Files}

This is a list of supplementary files associated with this preprint. Click to download.

- STROBEchecklistPBNBMCPH.docx

- BMCPHSuppTable2.docx

- BMCPHSuppTable1.docx

- Supplementaryfile1.xlsx 